\title{
Proteins Specified by Herpes Simplex Virus
}

\author{
V. Purification and Structural Proteins of the Herpesvirion \\ PATRICIA G. SPEAR AND BERNARD ROIZMAN \\ Department of Microbiology, The University of Chicago, Chicago, Illinois 60637
}

Received for publication 13 September 1971

\begin{abstract}
We are reporting a procedure for the purification of herpes simplex enveloped nucleocapsids (virions), an evaluation of the purification procedure and the results of analyses of the virion proteins by high-resolution acrylamide gel electrophoresis. The data may be summarized as follows. (i) The procedure for the purification of virions consists of careful extraction of cytoplasm to prevent nuclear breakage, separation of enveloped nucleocapsids from soluble proteins and membrane vesicles by rate zonal centrifugation of cytoplasmic extracts through dextran 10 gradients, treatment with urea to dissociate virus-debris aggregates, and, lastly, separation of virions from naked nucleocapsids and free membranes by isopycnic flotation in discontinuous sucrose gradients. (ii) Purity was evaluated in three ways, i.e., electron microscopic examination, analysis of purified virions produced in cells labeled with amino acids before infection, and analysis of purified virions from artificial mixtures of infected and labeled, uninfected cells. The extent of purification was 120to 200 -fold with respect to host proteins. Residual contaminants were identified as host and viral constituents of membrane vesicles. Residual host proteins are very likely contaminants and not structural components of the virion. (iii) Analyses by staining and autoradiography of structural proteins of purified virions in $6,7,8.5$, 9, and $14 \%$ acrylamide gels revealed 24 bands of proteins and glycoproteins made and labeled after infection. Co-electrophoresis of viral proteins with six known standards ranging from 25,700 to 220,000 daltons in molecular weight in $6,7,8.5$, and $9 \%$ acrylamide gels indicate that viral proteins range from 25,000 to 275,000 daltons. The sum of the molecular weights of viral proteins is 2,580,000 daltons. Assuming that messenger transcription is asymmetric and noncomplementary, this corresponds to $47 \%$ of the genetic information of the virus. (iv) The nonionic detergent NP-40 removes from purified virions some nonglycosylated proteins and a large fraction of the glycosylated proteins. It leaves behind traces of the envelope visible in the electron microscope as well as some glycoproteins thought to be in the envelope.
\end{abstract}

Virus preparations of demonstrable purity with respect to the molecules of interest are a prerequisite for analyses designed to quantitate and enumerate the structural components. Herpesviruses are notoriously difficult to purify for a number of reasons which stem from the site of maturation and complexity of the virion. Briefly, (i) herpesviruses acquire an envelope from the inner lamella of the nuclear membrane $[4,23,24$; B. Roizman and P. G. Spear, In Dalton and Haguenau (ed.), "Atlas of viruses," in press] and accumulate in the perinuclear space and in the cysternae of the endoplasmic reticulum $(19,23)$. Virus release from the infected cells is inefficient (11) and acquires momentum only after the infected cell disintegrates, spilling both virus and debris. In our hands, extracellular virus from cells in culture is frequently enclosed in a damaged envelope (permeable to negative stain) and is not a satisfactory source of virus for analysis. On the other hand, separation of intracellular virus from cellular organelles and particularly from membrane vesicles generated during the disruption of the cell presents special problems. The difficulty is compounded by the fact that the membranes of infected cells carry virus-specific proteins (13, 21,27 ). (ii) Infected cells yield not only enveloped nucleocapsids (virions) but also naked nucleocapsids in ratios which differ greatly from one cell line to another. An additional complication is that the envelope of the herpesvirion is relatively unstable.

In the past several years a number of labora- 
tories have reported on the structural proteins of enveloped $(2,12,17,27)$ and naked herpesvirus nucleocapsids (2, 18). Abodeely et al. (2) were able to obtain quite pure preparations, by electron microscopic criteria, of enveloped equine abortion virus from viremic hamsters. By using the technique of acrylamide gel electrophoresis, they resolved 20 proteins in the virion and 14 in the naked nucleocapsids obtained by treatment of virions with the nonionic detergent Nonidet P-40 (NP-40) and sonic treatment. Due largely to the infeasibility of isotopically labeling viral or host protein in the hamster, the authors were unable to identify the various nucleocapsid proteins with virion proteins or to determine whether any proteins in the virion were host specified. Robinson and Watson (18) obtained naked nucleocapsids of herpes simplex virus which were extensively purified according to several criteria. These authors reported the possible existence of as many as 11 polypeptides in the naked nucleocapsid. Although two preceding papers in this series $(13,27)$ reported electropherograms of partially purified particles, the low resolution of the electropherogram technique (26) used in the studies precluded enumeration of the protein bands in the gel. Olshevsky and Becker (17) and Kaplan and Ben-Porat (12) reported on the structural proteins of herpes simplex and pseudorabies viruses, respectively, but they found fewer proteins than Abodeely et al. (2). We must agree, however, with Robinson and Watson (18) that none of these studies (12, $13,17,27)$ have presented adequate criteria for the purity of the virus preparations used.

In this paper we are reporting a new procedure for the purification of herpesvirions and an evaluation of the procedure. The protein composition of the purified preparations was analyzed by electrophoresis in acrylamide gels by utilizing a high-resolution technique developed independently by Dimmock and Watson (6)' and by Laemmli (15). Evidence is presented that cellular proteins are probably not components of the mature virion and that the virus-specific structural proteins are more numerous than previously suspected. For the purposes of this paper, we are defining as virus-specific virion proteins those structural components which are made after infection and which do not become labeled when cells are fed radioactive precursors before infection. Clearly this is a provisional definition pending, ultimately, the synthesis of these structural proteins in a cell-free system with a defined viral messenger ribonucleic acid (mRNA).

\section{MATERIALS AND METHODS}

Cells. Human epidermoid carcinoma no. 2 (HEp-2) cells were grown in Eagle's minimal essential medium
(EMEM) supplemented with $10 \%$ calf serum, $0.001 \%$ ferric nitrate, and $1 \%$ sodium pyruvate.

Virus. A strain of herpes simplex virus subtype 1, designated $\mathrm{F}$, was used in all the studies reported here. The procedures for the assay of this virus in terms of plaque-forming units (PFU) and some pertinent characteristics of this strain have been previously reported $(7,13,14)$.

Reagents. The following radiochemicals were obtained from New England Nuclear Corp., Boston, Mass.: uniformly labeled $\mathrm{L}$-amino acid-14 $\mathrm{C}$ mixture and generally labeled L-amino acid- ${ }^{3} \mathrm{H}$ mixture, each consisting of 15 amino acids; D-glucosamine- $1-{ }^{14} C$ hydrochloride (40 to $50 \mathrm{mCi} / \mathrm{mmole}$ ); D-glucosamine$6{ }^{3} \mathrm{H}$ - hydrochloride (1 to $2 \mathrm{Ci} / \mathrm{mmole}$ ). Other reagents used were acrylamide from $\mathrm{K} \& \mathrm{~K}$ Laboratories, Plainview, N.Y.; $N, N^{\prime}$-methylenebisacrylamide and $N, N, N^{\prime}, N^{\prime}$-tetramethylethylenediamine (TEMED) from Eastman Chemicals, Rochester, N.Y.; dextran 10 from Pharmacia, Uppsala, Sweden; Coomassie Brilliant Blue from Colab Laboratories Inc., Glenwood, Ill.; ultrapure urea from Mann Research Laboratories, New York, N.Y.; Soluene-100 from Packard Instrument Co., Downers Grove, Ill.; ovalbumin (grade V) and $\alpha$-chymotrypsinogen-A (bovine pancreas, type II) from Sigma Chemical Co., St. Louis, Mo.; lactoperoxidase (B grade), bovine serum albumin (crystallized, A grade) from Calbiochem, Los Angeles, Calif.; $\beta$-galactosidase from Worthington Biochemical Corp., Freehold, N.J. Myosin was the kind gift of D. Fischman. NP-40 was a gift of Shell Chemical Co., New York, N.Y.

Infection of cells. Cells, grown in roller bottles or 32-oz bottles, were infected with virus at an input multiplicity of 5 to 10 PFU per cell. The virus was added to the cells in a small volume of medium $199-1 \%$ calf serum $(25 \mathrm{ml}$ for roller bottles, $9 \mathrm{ml}$ for $32-\mathrm{oz}$ bottles) and the cultures were rolled or shaken for $2 \mathrm{hr}$ at $37 \mathrm{C}$ to allow adsorption to take place. The inoculum was replaced with medium $199-1 \%$ calf serum and incubation was continued at $37 \mathrm{C}$.

Labeling of cells. Cellular proteins were labeled by incubating uninfected cells for intervals up to $48 \mathrm{hr}$ in EMEM-10\% dialyzed calf serum containing one-fifth to one-half the usual concentrations of amino acids plus ${ }^{14} \mathrm{C}$-amino acid mixture at 0.25 to $0.5 \mu \mathrm{Ci}$ per $\mathrm{ml}$. To label viral proteins, infected cells were incubated between 5 and 18 to $24 \mathrm{hr}$ postinfection in EMEM-1\% dialyzed calf serum containing one-tenth the usual concentration of all amino acids except for arginine, which was present at the usual concentration, and ${ }^{14} \mathrm{C}$-amino acid mixture $(0.5$ to $0.67 \mu \mathrm{Ci} / \mathrm{ml})$ or ${ }^{3} \mathrm{H}$-amino acid mixture $(3 \mu \mathrm{Ci} / \mathrm{ml})$. Viral glycoproteins were labeled by incubating infected cells, between 5 and 18 to $24 \mathrm{hr}$ postinfection, in medium (either medium 199-1\% calf serum or EMEM-1\% dialyzed calf serum modified as above) containing ${ }^{14} \mathrm{C}$-glucosamine $(0.5 \mu \mathrm{Ci} / \mathrm{ml})$ or ${ }^{3} \mathrm{H}$-glucosamine $(5 \mu \mathrm{Ci} / \mathrm{ml})$. We previously reported $(13,27)$ that $92 \%$ of the glucosamine label, incorporated into infectedcell macromolecules during similar conditions of incubation, was recovered as glucosamine and galactosamine.

Purification of virus. Cells infected for 18 to $24 \mathrm{hr}$ were scraped off the glass surface on which they were 
grown and collected by low-speed centrifugation. The procedure for the purification of virus from infected cells involved essentially three steps, all carried out at 0 to 4 C. (i) The first step consisted of disruption of the cells and separation of the cytoplasm from nuclei. Careful preparation of cytoplasm is essential. Isotonic sucrose solutions were used to stabilize the nuclei and prevent leakage of nucleocapsids and of nucleoproteins which tend to aggregate membranous structures. The packed infected cells were suspended in approximately two volumes of $1 \mathrm{mM}$ phosphate buffer, $p H$ 7.4, and then disrupted with four strokes of a Dounce homogenizer. Immediately afterwards, sufficient $60 \%$ (w/w) sucrose was added to yield a final concentration of $0.25 \mathrm{M}$. The cytoplasm was then separated from the nuclei by centrifugation at $1,500 \mathrm{rev} / \mathrm{min}$ for $10 \mathrm{~min}$ in the PR-2 international refrigerated centrifuge. (ii) The second step consisted of rate zonal centrifugation of the cytoplasmic extract on dextran 10 gradients. This centrifugation effectively separates virions from soluble proteins, which remain on the top of the gradient; from aggregates of virions, cytoplasmic organelles and large debris, which pellet; and from most of the cellular membrane vesicles, which remain near the top of the gradient. Dextran specifically is used because of its low osmolarity; presumably intact membrane vesicles stay distended rather than collapsed and sediment more slowly than the virions which have a high density core (28). In this step 2-ml samples of cytoplasm were layered on $36-\mathrm{ml}$ dextran 10 gradients $\left(1.04\right.$ to $\left.1.09 \mathrm{~g} / \mathrm{cm}^{3}\right)$ made up in $1 \mathrm{~mm}$ phosphate buffer. The dextran 10 solutions were filtered through Millipore $0.45-\mu \mathrm{m}$ membrane filters prior to use. The gradients were centrifuged for $1 \mathrm{hr}$ at $20,000 \mathrm{rev} / \mathrm{min}$ in the Beckman SW27 rotor. After centrifugation, virions were found in a diffuse light-scattering band just above the middle of the tube. This band, containing partially purified, mostly enveloped virus, was aspirated with a needle and syringe by puncturing the side of the tube. The virus band was made $0.5 \mathrm{M}$ with respect to urea by the addition of an appropriate amount of $5 \mathrm{M}$ urea and was sonically treated for $\mathbf{5} \mathrm{sec}$ to dissociate aggregates of virions and host membrane vesicles. For analysis of partially purified virus, the dextran band was diluted approximately fourfold with $0.01 \mathrm{M}$ tris(hy-

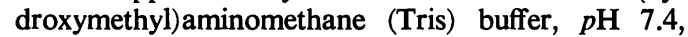
and the virions were pelleted by centrifugation at $25,000 \mathrm{rev} / \mathrm{min}$ for 1 to $2 \mathrm{hr}$ in the SW27 rotor. The pellets were suspended in a small volume of $0.01 \mathrm{M}$ Tris and stored at $-20 \mathrm{C}$ prior to analysis by acrylamide gel electrophoresis. Viral proteins were quantitatively recovered in the pellets after centrifugation. It is noteworthy that relatively brief $(1 \mathrm{hr})$ exposure of enveloped virus to concentrations of urea as high as $1.5 \mathrm{M}$ does not affect the infectivity of the virus at room temperature (20). It should also be pointed out that the centrifugation through dextran gradients offers no advantages for the purification of virions with damaged envelopes or of naked nucleocapsids. (iii) The third step in the purification procedure was designed to separate the virions from remaining contaminants, i.e., membrane fragments and small amounts of unenveloped nucleocapsids, by flotation of the partially purified virus through a discontinu- ous sucrose gradient. Membrane contaminants float to a lower density at a higher position in the tube than the bulk of the virions, whereas nucleocapsids, because of their higher density, will pellet. In this step the sonically treated dextran band was made $50 \%(w / w)$ with respect to sucrose by the addition of solid sucrose. Eight- to $12-\mathrm{ml}$ samples of this solution were placed in 38-ml tubes; discontinuous sucrose gradients were formed by the successive layering of 40,30 , and $20 \%$ sucrose (made up in $0.01 \mathrm{M}$ Tris buffer) on top of the $50 \%$ sucrose-virus layer. These gradients were then centrifuged at $25,000 \mathrm{rev} / \mathrm{min}$ for $18 \mathrm{hr}$ in the SW27 rotor. Membrane contaminants and some virus floated to the 30 to $40 \%$ interface; the bulk of the virions floated to the 40 to $50 \%$ interface and were aspirated by needle and syringe. The floated virus band was diluted approximately fourfold with $0.01 \mathrm{M}$ Tris buffer, layered over $10 \mathrm{ml}$ of $10 \%$ sucrose in $2 \mathrm{M}$ urea, $0.01 \mathrm{M}$ Tris buffer in a $38-\mathrm{ml}$ tube, and centrifuged at $25,000 \mathrm{rev} / \mathrm{min}$ for 2 hr in the SW27 rotor. The virus pellets were suspended in a small volume of $0.01 \mathrm{M}$ Tris buffer and frozen at $-20 \mathrm{C}$. Viral proteins were quantitatively recovered in the pellets.

We have centrifuged partially purified virus (dextran band) in a potassium tartrate density gradient instead of a discontinuous sucrose gradient as the third step of purification and achieved comparable results as far as the protein composition of the final product is concerned. Briefly, partially purified virions were pelleted from a dextran virus band as described above, suspended in a small volume of $0.01 \mathrm{M}$ Tris buffer, and layered on a $16-\mathrm{ml} 10$ to $50 \%$ (w/w) potassium tartrate gradient. The gradient was centrifuged for $2 \mathrm{hr}$ at $25,000 \mathrm{rev} / \mathrm{min}$ in the SW27 rotor. Virions were found in a light-scattering band just below the middle of the tube. This band was aspirated by puncturing the side of the tube with needle and syringe, diluted twofold with $0.01 \mathrm{~m}$ Tris buffer, and centrifuged for $1 \mathrm{hr}$ at $40,000 \mathrm{rev} / \mathrm{min}$ in the 65 rotor to pellet the virions. Although this alternate procedure is faster and results in greater recovery of infectivity, flotation through discontinuous sucrose gradients was used exclusively to prepare purified virions for the analyses reported in this paper. It should be emphasized that the protein compositions of the final preparations obtained by the two procedures are qualitatively and quantitatively indistinguishable.

Treatment of virus with NP-40. A pellet of partially purified virus, obtained from the dextran gradient fraction as described above, was resuspended in 0.5 $\mathrm{ml}$ of $0.01 \mathrm{M}$ Tris buffer (approximately $500 \mu \mathrm{g}$ of protein/0.5 ml). Ten per cent $\mathrm{NP}-40$ and $1.5 \mathrm{M} \mathrm{NaCl}$ were added to yield final concentrations of $1 \%$ and $0.15 \mathrm{M}$, respectively. After $15 \mathrm{~min}$ at $0 \mathrm{C}$, the detergent-treated virus was layered on a $16-\mathrm{ml} 20$ to $50 \%$ sucrose gradient in $0.15 \mathrm{M} \mathrm{NaCl}, 0.01 \mathrm{M}$ Tris buffer and centrifuged at $25,000 \mathrm{rev} / \mathrm{min}$ for $45 \mathrm{~min}$ in the SW27 rotor (small buckets). A light-scattering band in the middle of the gradient was aspirated with a needle and syringe, diluted approximately three- to fourfold with $0.01 \mathrm{M}$ Tris, and centrifuged for $1 \mathrm{hr}$ at $40,000 \mathrm{rev} / \mathrm{min}$ in the 65 rotor. The pellet was stored at $-20 \mathrm{C}$ prior to acrylamide gel electrophoresis.

Acrylamide gel electrophoresis. Analyses of pro- 
teins by acrylamide gel electrophoresis were carried out in a discontinuous system as described by Dimmock and Watson (6) and by Laemmli (15). This procedure combines the original disc electrophoresis method of Davis (5) with the use of sodium dodecyl sulfate (SDS) to denature proteins (29). The solution from which the main gel was polymerized contained $0.375 \mathrm{M}$ Tris-hydrochloride $(p \mathbf{H} 8.8), 0.1 \%$ SDS, $0.03 \%$ (v/v) TEMED, $0.035 \%$ (w/v) ammonium persulfate with concentrations of acrylamide ranging from 6 to 14\%, maintaining a bis-acrylamide:acrylamide ratio of $1: 38$. The stacker gel consisted of $0.125 \mathrm{M}$ Tris-hydrochloride, $p \mathrm{H} \quad 7.0,0.1 \%$ SDS, $0.03 \%$ (v/v) TEMED, $0.07 \%$ (w/v) ammonium persulfate, $3 \%$ acrylamide, $0.08 \%$ bis-acrylamide. The gels $(8 \mathrm{~cm}$ of main gel, $2 \mathrm{~cm}$ of stacker gel) were formed in siliconized glass tubes of $6 \mathrm{~mm}$ inside diameter or between two glass plates separated by 2-mm spacers. Electrophoresis of proteins on the flat gel slab $(2 \mathrm{~mm}$ thick by $100 \mathrm{~mm}$ wide by $100 \mathrm{~mm}$ long, including the main gel and stacker) was carried out in an apparatus constructed from the design furnished in part by Lim et al. (16). The electrode buffer at $p \mathrm{H} 8.5$ contained $0.025 \mathrm{M}$ Tris, $0.192 \mathrm{M}$ glycine, and $0.1 \%$ SDS. Immediately prior to electrophoresis, the proteins were denatured and solubilized by the addition of concentrated reagents to yield final concentrations of $0.05 \mathrm{M}$ Tris-hydrochlo-

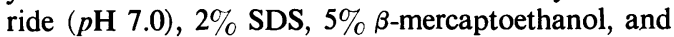
$0.005 \%$ bromophenol blue followed by boiling for 2 min. The solubilized proteins in volumes of 50 to $200 \lambda$ were subjected to electrophoresis at a constant current of 3 to 4 ma per gel cylinder or 24 ma per gel slab. Electrophoresis was stopped when the bromophenol blue reached a fixed distance from the top of the main gel.

Proteins in the gel were stained with Coomassie Brilliant Blue by one of two procedures. (i) The gels were immersed overnight in $15 \%$ trichloroacetic acid to fix the proteins, then in $7 \%$ acetic acid, $25 \%$ methanol for $2 \mathrm{hr}$, finally in $0.25 \%$ Coomassie Brilliant Blue, $7 \%$ acetic acid, $25 \%$ methanol for 4 to 18 $\mathrm{hr}$ to stain the proteins. Gels were destained in several changes of $7 \%$ acetic acid, $25 \%$ methanol over a period of 3 days. (ii) Following the procedure of Fairbanks, et al. (9), gels were fixed and stained by soaking overnight in $0.04 \%$ Coomassie Brilliant Blue, $10 \%$ acetic acid, $25 \%$ isopropanol. Gels were destained in several changes of $10 \%$ acetic acid, $10 \%$ isopropanol over a period of 1 to 2 days.

Analyses of radioactive proteins in acrylamide gels were done by autoradiography or by liquid scintillation counting. In preparation for the autoradiography of ${ }^{14} \mathrm{C}$-labeled proteins, gel slabs or gel cylinders cut in half longitudinally were dried on filter paper essentially as described by Fairbanks et al. (8). The half gel cylinders were dried with the cut edge uppermost and exposed. The flattened, dried gels were placed in contact with Kodak Medical X-Ray film NS-54T and stored in light-tight folders under a heavy weight for the exposure interval. The film was processed with Kodak D-19 developer and Kodak Rapid-Fix. For liquid scintillation counting, gel cylinders, half gel cylinders, or strips of gel slabs were sliced laterally into 1-mm segments. Each slice was placed in a scintillation vial to which was added $0.7 \mathrm{ml}$ of Soluene-100. After incubation of the capped vial for $3 \mathrm{hr}$ at $60 \mathrm{C}$, $10 \mathrm{ml}$ of scintillation fluid [28.2 $\mathrm{g} \mathrm{2,5-diphenyloxa-}$ zole and $1.13 \mathrm{~g} \mathrm{1,4-bis-[2-(4-methyl-5-phenyloxazo-}$ lyl)]-benzene per gal of toluene] was added to each vial and mixed thoroughly. Radioactivity was measured after $6 \mathrm{hr}$ at $4 \mathrm{C}$.

The absorbance of bands in stained gels and autoradiograms was measured either with the Gilford gel scanner attachment and Gilford recording spectrophotometer or with the Joyce, Loebel \& Co. doublebeam recording microdensitometer.

Estimation of molecular weights of viral proteins. The procedure used was that of Shapiro et al. (25). Briefly, the molecular weights of herpesvirus proteins were estimated by determining their migration rates relative to the bromophenol blue marker in four concentrations of acrylamide-6, 7, 8.5, and $9 \%$ - and by comparing their relative migration rates with those of proteins whose molecular weights are well characterized. Several comments should be made concerning the behavior of the protein standards in the gels of various concentrations. (i) For the standard proteins smaller than 100,000 daltons, a plot of logarithm of molecular weight versus relative migration rate yielded a straight line for each gel concentration. (ii) In $7 \%$ acrylamide, a linear relationship between logarithm of molecular weight and relative migration rate was found to hold for all the protein standards used ranging from 43,000 to 220,000 daltons. (iii) However, in $9 \%$ acrylamide, the standard proteins larger than 100,000 daltons migrated faster than would be expected if they had obeyed the inverse logarithmic function between molecular weight and relative migration rate which holds for $7 \%$ gels. A smooth curved line could be drawn to fit the points (34); molecular weights estimated from this curved line agreed well with those estimated from the straight line obtained in $7 \%$ gels.

Electron microscopy. To prepare sectioned material for examination, pellets were obtained by centrifugation of partially purified and purified virus as described above and then fixed in $2 \%$ glutaraldehyde buffered at $p \mathrm{H} 7.2$ with $0.1 \mathrm{M}$ sodium cacodylate, postfixed in $2 \%$ osmium buffered at $p \mathbf{H ~} 7.4$ with $0.067 \mathrm{M}$ s-collidine buffer, dehydrated in an ethanol series, and embedded in Epon. Thin sections of the embedded material were stained with lead citrate and uranyl acetate prior to examination in an AEIEM6B microscope. Negatively stained whole mounts were prepared by touching a grid coated with Formvar and carbon to a virus suspension, washing the grid with several drops of water, and touching the grid to a solution of $2 \%$ sodium silicotungstate containing $0.01 \%$ albumin. Excess stain was removed with filter paper and the grid was allowed to dry prior to examination.

\section{RESULTS}

The yield and purity of the herpesvirion preparations obtained by the procedure described above was determined in several experiments. 
Electron microscopic analysis of purified virus. The purpose of these analyses was to determine the nature of the products obtained in the course of the purification. Electron microscopic analyses were done both by negative-staining technique and by thin-section technique. Although the negative-staining technique is more useful for the analysis of the integrity of the enveloped virus, since under appropriate conditions negative stains do not penetrate the intact envelope (19, 33 ), thin sections reveal more accurately the actual contents of the material being tested. Electron photomicrographs of thin sections of purified virus are shown in Fig. 1. The results of the electron microscopic analyses may be summarized as follows. (i) The partially purified virus banded in dextran gradients consisted almost exclusively of intact enveloped nucleocapsids. However, membrane contaminants were occasionally seen in thin sections. (ii) The band obtained by flotation through the discontinuous sucrose gradient also consisted almost exclusively

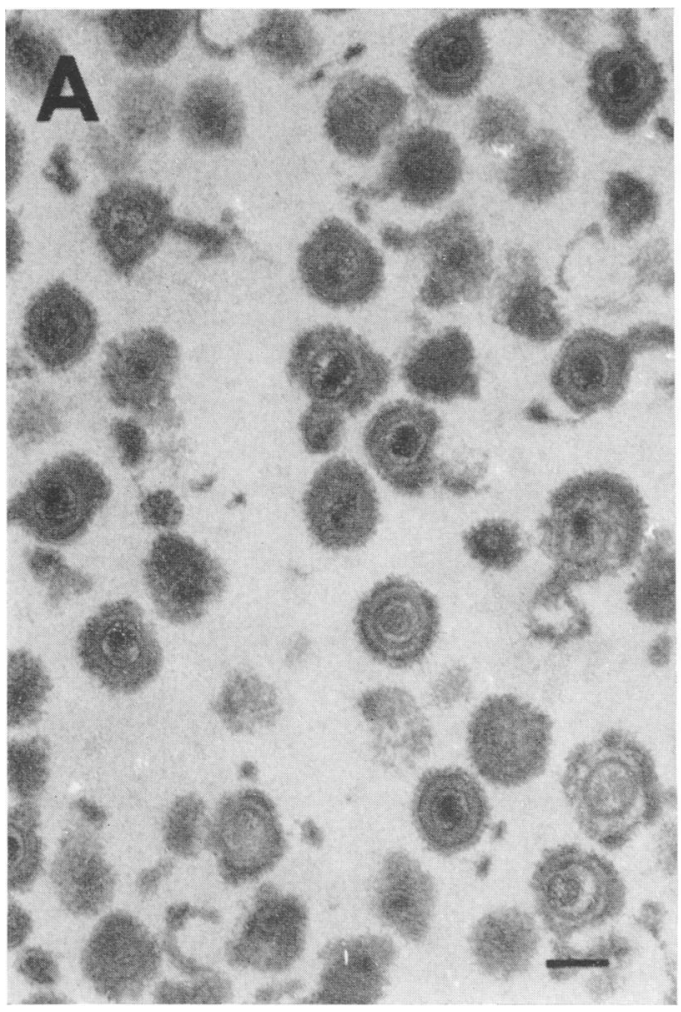

of enveloped nucleocapsids. However, a large percentage of these particles exhibited loss of integrity of the envelope. Membrane contaminants were extremely rare.

Estimation of the enrichment of viral proteins with respect to host proteins during the course of purification. In this series of experiments we took advantage of the fact that host protein synthesis ceases after infection and that the proteins labeled 4 to $5 \mathrm{hr}$ postinfection and later are probably specified by the virus $(27,29,31)$. Two kinds of experiments were done. In the first, virus was purified from an artificial mixture of infected cells labeled with ${ }^{3} \mathrm{H}$-amino acids from 5 to $24 \mathrm{hr}$ postinfection and uninfected cells were labeled with ${ }^{14} \mathrm{C}$-amino acids for $48 \mathrm{hr}$. In the second, virus was purified from two separate but parallel batches of cells, one labeled with ${ }^{14} \mathrm{C}$ amino acids from 5 to $20 \mathrm{hr}$ postinfection and the other labeled with ${ }^{14} \mathrm{C}$-amino acids for $48 \mathrm{hr}$ prior to infection. The cells labeled prior to infection were washed several times with nonradio-

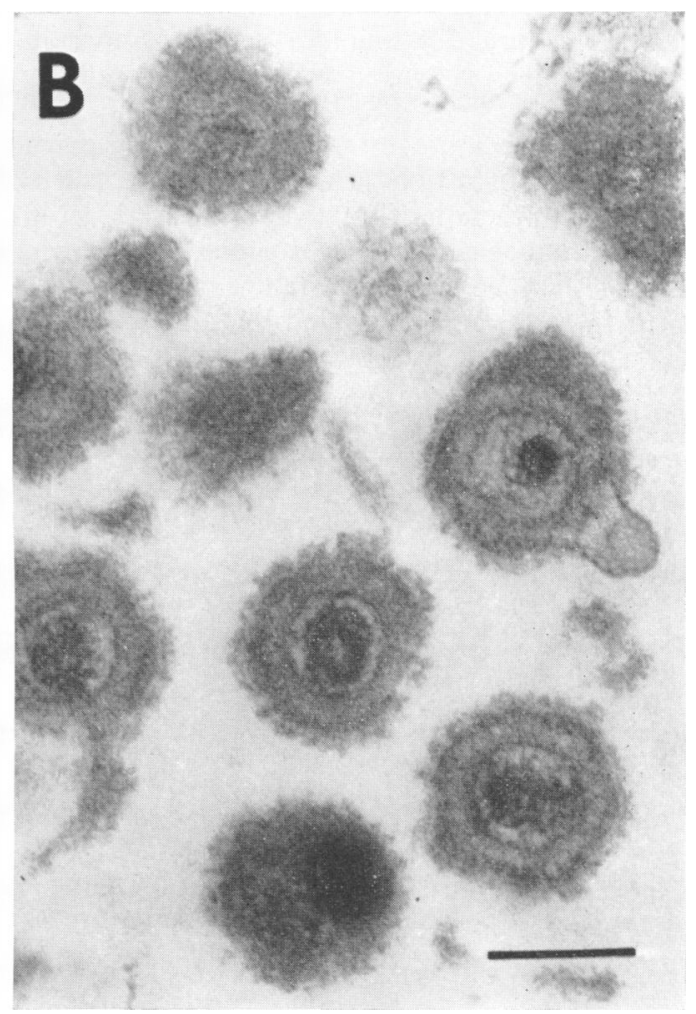

FIG. 1. Electron micrographs of thin sections of pellets obtained by centrifugation of partially purified $(A)$ and purified $(B)$ virus. Both fields show enveloped virions sectioned through various planes. Naked nucleocapsids were only rarely seen. On most particles, the envelope very tightly adheres to the nucleocapsid such that the outer dimension of the nucleocapsid is not clearly delineated. Note the projections on the outer surface of the envelope. Bars represent $100 \mathrm{~nm}$. 
active medium containing twice the usual concentrations of amino acids and incubated in the same medium for $3 \mathrm{hr}$ immediately prior to infection, to insure that viral proteins would not become labeled. Recoveries of radioactivity from these various preparations during the course of purification are shown in Table 1 . The calculated ratios of counts per minute in viral proteins to counts per minute in cellular proteins recovered in each step of the procedure showed an approximate 20 -fold enrichment of virusspecified proteins with respect to cellular proteins in both experiments. This is the lower limit of the degree of purification of virion proteins with respect to cellular proteins and is probably much too low an estimate since infected-cell homogenates contain virus-specified proteins which are labeled after infection but are not virion constituents, i.e., membrane glycoproteins $(13,27$; B. Roizman and P. G. Spear, Proc. 1st Symp. Nucleic Acid Synthesis Viral Infec., in press), naked nucleocapsids, nonstructural proteins, and structural proteins which have not yet aggregated to form nucleocapsids. The purification procedure discriminates against nonvirion virus-specified proteins as well as against cellular proteins.

A more accurate estimate of the degree of purification of virion proteins could be calculated if the fraction of total virus-specific lacel in the cell homogenate which is actually present in virions were known. This datum can be calculated from the data presented in Table 2 . In this experiment virus was purified from cells incu- bated with ${ }^{14} \mathrm{C}$-amino acids after infection to label viral proteins only; both radioactivity and infectivity were monitored throughout the purification. The number of PFU bears some constant relation to the number of virions provided there are no losses of biological activity and no aggregation. In this and in other experiments, we observed only a slight loss of infectivity after centrifugation in the dextran density gradient but a very substantial loss (approximately 95\%) after flotation of the virus in the sucrose gradient. The loss in infectivity parallels and may be accounted for by the loss of integrity of the virion envelope as seen in both negatively stained preparations and in thin sections. The results indicate the following. (i) Without making any corrections for the loss of infectivity, the observed PFU-counts per minute ratio for the partially purified virus recovered from the dextran gradient indicates a sixfold enrichment of virions with respect to labeled proteins $(1.96 \div 0.31)$; therefore no more than one-sixth of the labeled proteins in the homogenate was present in virions. Using this figure in conjunction with the data presented in Table 1, the degree of purification just to the dextran step alone becomes at least 120 -fold. (ii) An estimate of the extent of purification throughout the whole procedure can be obtained by correcting the PFU-counts per minute ratios for the loss of infectivity, as indicated in the legend to Table 2. The corrected PFU-counts per minute ratios indicate a 10 -fold enrichment of virions with respect to virus-specified (labeled) proteins during the entire proce-

TABLE 1. Purification of herpesvirions: separation of labeled viral and host proteins during purification

\begin{tabular}{|c|c|c|c|c|c|c|}
\hline \multirow{2}{*}{ Expt conditions } & \multirow{2}{*}{ Fraction } & \multicolumn{2}{|c|}{ Label in viral proteins } & \multicolumn{2}{|c|}{$\begin{array}{l}\text { Label in cellular } \\
\text { proteins }\end{array}$} & \multirow{2}{*}{$\begin{array}{l}\text { Ratio: } \\
\text { counts } \\
\text { viral per } \\
\text { counts } \\
\text { cellular }\end{array}$} \\
\hline & & $\left|\begin{array}{l}\text { Counts per } \\
\min \times 10^{-3}\end{array}\right|$ & $\begin{array}{c}\text { Fraction } \\
\text { recovered }\end{array}$ & $\begin{array}{c}\text { Counts per } \\
\min \times 10^{-3}\end{array}$ & $\begin{array}{l}\text { Fraction } \\
\text { recovered }\end{array}$ & \\
\hline $\begin{array}{l}\text { Expt 1: virus purified from an } \\
\text { artificial mixture of infected } \\
\text { cells labeled with }{ }^{3} \mathrm{H} \text {-amino } \\
\text { acids postinfection and unin- } \\
\text { fected cells labeled with }{ }^{14} \mathrm{C} \text { - } \\
\text { amino acids }\end{array}$ & $\begin{array}{l}\text { Homogenate } \\
\text { Cytoplasm } \\
\text { Virus band (dextran) } \\
\text { Virus band (flotation) }\end{array}$ & $\begin{array}{r}2,690 \\
711 \\
62.0 \\
59.5\end{array}$ & $\begin{array}{l}(1.00)^{a} \\
0.26 \\
0.023 \\
0.022\end{array}$ & $\begin{array}{r}2,170 \\
584 \\
4.44 \\
2.16\end{array}$ & $\begin{array}{c}(1.00) \\
0.27 \\
0.002 \\
0.001\end{array}$ & $\begin{array}{r}1.24 \\
1.22 \\
13.96 \\
27.55\end{array}$ \\
\hline $\begin{array}{l}\text { Expt 2: virus purified in two } \\
\text { separate but parallel prepara- } \\
\text { tions }^{b}\end{array}$ & $\begin{array}{l}\text { Homogenate } \\
\text { Cytoplasm } \\
\text { Virus band (dextran) } \\
\text { Virus band (flotation) }\end{array}$ & $\begin{array}{r}31,340 \\
9,270 \\
971.6 \\
559.8\end{array} \mid$ & $\begin{array}{l}(1.00)^{a} \\
0.30 \\
0.031 \\
0.018\end{array}$ & $\begin{array}{r}23,960 \\
7,550 \\
51.8 \\
21.5\end{array}$ & $\begin{array}{l}(1.00) \\
0.32 \\
0.002 \\
0.001\end{array}$ & $\begin{array}{r}1.31 \\
1.23 \\
18.76 \\
26.04\end{array}$ \\
\hline
\end{tabular}

"For convenience, we are setting the total counts in virus-specific proteins contained in the homogenate to 1.00 . Comparisons of counts in purified virus with those in the crude homogenate make the implicit assumption that all the counts in the homogenate are in virions. This is incorrect. Correction factors obtained from Table 2 are given in Results.

${ }^{b}$ Preparation 1: Cells labeled with ${ }^{14} \mathrm{C}$-amino acids from 5 to $20 \mathrm{hr}$ postinfection; preparation 2: cells labeled with ${ }^{14} \mathrm{C}$-amino acids for $48 \mathrm{hr}$ prior to infection. 
TABLE 2. Purification of herpesvirions: recovery of infectivity and virus-specific label

\begin{tabular}{|c|c|c|c|c|c|c|c|c|}
\hline \multirow[t]{3}{*}{ Fraction } & $\begin{array}{l}{ }^{14} \mathrm{C} \text {-Counts } \\
\text { per } \\
\min \times 10^{-3}\end{array}$ & $\begin{array}{l}\text { Fraction } \\
\text { recovered }\end{array}$ & $\mathrm{PFU} \times 10^{-7}$ & $\begin{array}{l}\text { Fraction } \\
\text { recovered }\end{array}$ & $\begin{array}{l}\text { PFU per } \\
\text { counts per } \\
\text { min } \times 10^{-3}\end{array}$ & $\begin{array}{c}\text { Corrected } \\
\operatorname{PFU}^{a} \times \\
10^{-i}\end{array}$ & $\begin{array}{c}\text { Fraction } \\
\text { recovered }\end{array}$ & $\begin{array}{c}\text { Corrected } \\
\text { PFU per } \\
\text { counts per } \\
\text { min } \times \\
10^{-3}\end{array}$ \\
\hline & \multicolumn{8}{|c|}{ Column no. } \\
\hline & 1 & 2 & 3 & 4 & 5 & 6 & 7 & 8 \\
\hline \multicolumn{9}{|l|}{ Step 1: cell fractionation } \\
\hline Homogenate. . . . . . . & 15,000 & $(1.00)$ & 457 & $(1.00)$ & 0.31 & 457 & $(1.00)$ & 0.31 \\
\hline Cytoplasm......... & 3,450 & 0.23 & 282 & 0.62 & 0.82 & 282 & 0.62 & 0.82 \\
\hline \multicolumn{9}{|l|}{ Step 2: dextran gradient } \\
\hline Input (cytoplasm) ... & 3,450 & $(1.00)$ & 282 & $(1.00)$ & 0.82 & 282 & $(1.00)$ & 0.82 \\
\hline Virus band .......... & 163 & 0.05 & 32 & 0.11 & 1.96 & 41 & 0.15 & 2.52 \\
\hline Remainder ${ }^{b}$ & 3,400 & 0.98 & 188 & 0.67 & 0.55 & 241 & 0.85 & 0.71 \\
\hline Total recovered & 3,563 & 1.03 & 220 & 0.78 & 0.62 & 282 & $(1.00)$ & 0.79 \\
\hline \multicolumn{9}{|l|}{ Step 3: flotation gradient } \\
\hline $\begin{array}{l}\text { Input }(\text { dextran virus } \\
\text { band }) \ldots \ldots\end{array}$ & 163.0 & $(1.00)$ & 32 & $(1.00)$ & 1.96 & 41 & $(1.00)$ & 2.52 \\
\hline Virus band........... & 98.8 & 0.61 & 1.2 & 0.038 & 0.12 & 35 & 0.85 & 3.54 \\
\hline Remainder...... & 55.4 & 0.34 & 0.22 & 0.006 & 0.04 & 6 & 0.15 & 1.08 \\
\hline Total recovered..... & 154.2 & 0.95 & 1.42 & 0.044 & 0.09 & 41 & $(1.00)$ & 2.66 \\
\hline
\end{tabular}

${ }^{a}$ Corrected plaque-forming units (PFU) were calculated on the assumption that losses in infectivity are due to changes in the biological properties of virions without significant changes in their physical properties. This assumption is in part justified by the fact that during flotation through the sucrose gradient-the single step which results in a 95\% loss of infectivity (column 4)-two-thirds of the material floats to a position characteristic of intact virions. Degradation products would either float to a higher level (envelopes) or remain in the sample layer or pellet (nucleoprotein). The corrections were done as follows: (i) No corrections were applied to the PFU quantitated in step 1 since all of the PFU in the homogenate are recovered in the cytoplasm plus nuclei. (ii) The fraction of input infectivity recovered from the dextran gradient was 0.78 (column 4). Based on the recovery of all counts and assuming random loss of infectivity, the observed PFU (step 2-column 3) were divided by 0.78 to yield the corrected PFU in column 6 . (iii) The cumulative fraction of infectivity recovered after steps 2 and 3 was $0.78 \times 0.044$. Based on the same considerations as in (ii), the observed PFU (step 3-column 3 ) were divided by this value to yield the corrected PFU in column 6.

${ }^{b}$ Note that infectious virus other than in the virus band was distributed throughout the gradient and in the pellet.

dure $(3.54 \div 0.31)$. In other words, no more than one-tenth of the label in the cell homogenate was actually present in virions. The 20-fold enrichment of virus-specified proteins with respect to cellular proteins, shown in Table 1 , actually represents a 200 -fold enrichment of virion proteins with respect to cellular proteins.

The same degree of purification may be calculated more directly from the data presented in Table 3. In this experiment the cells were labeled with ${ }^{14} \mathrm{C}$-amino acids for $48 \mathrm{hr}$ before infection. During and after infection, the cells were incubated in a medium containing excess unlabeled amino acids to ensure that proteins made after infection did not become labeled. As in the preceding experiments, the purification procedure was monitored for both radioactivity and infec- tivity. As shown in Table 3 , the PFU-counts per minute ratio (uncorrected) for the partially purified virus banded in the dextran density gradient is nearly 100 times higher than that of the crude homogenate. On the basis of the find-

TABle 3. Purification of infectious herpesvirions with respect to labeled host proteins

\begin{tabular}{|c|c|c|c|}
\hline Fraction & $\begin{array}{c}\text { Cellular } \\
\text { protein } \\
\text { (counts per } \\
\text { min } \times 10^{-3} \text { ) }\end{array}$ & $\begin{array}{l}\mathrm{PFU}^{a} \\
\times 10^{-6}\end{array}$ & $\begin{array}{c}\text { PFU per } \\
\text { counts } \\
\text { per min } \\
\times 10^{-3}\end{array}$ \\
\hline Homogenat & 23,960 & 21,030 & 0.9 \\
\hline Cyioplasm. . & 7,550 & 20,020 & 2.7 \\
\hline Dextran virus band. & 51.8 & 4,130 & 80.0 \\
\hline
\end{tabular}

"Plaque-forming units. 
ing shown in Table 1, that flotation improves the purity of the virus preparation with respect to host proteins approximately twofold, it would follow that, if there were no loss of infectivity during flotation, the expected PFU-counts per minute ratio in the virus band from the sucrose gradient would be 200 times higher than that of the crude homogenate, indicating a 200-fold enrichment of virions with respect to cellular proteins.

Nature of the impurities present in the virus banded in the dextran density gradient and floated in the discontinuous sucrose gradient. As indicated in the preceding sections, the probable impurities of concern to us were membrane vesicles resembling virions hydrodynamically. Since purified membrane preparations of infected cells invariably contain host protein (27; Heine, Spear, and Roizman, manuscript in preparation), it was of interest to determine whether purified virions contained host proteins. Two series of experiments were done.

In the first series, virions were prepared from an artificial mixture of ${ }^{3} \mathrm{H}$-amino acid-labeled infected cells and of ${ }^{14} \mathrm{C}$-amino acid-labeled uninfected cells. In the second experiment, the cells were labeled with ${ }^{14} \mathrm{C}$-amino acids for $48 \mathrm{hr}$ before infection. The cells were then washed, incubated in the presence of an excess of unlabled amino acids, and infected as described previously. The electrophoretic profiles of the proteins present in partially purified (dextran gradients) and purified (flotation in sucrose gradients) virions, prepared from the artificial mixture of infected and uninfected cells and from cells labeled before infection, are shown in Fig. 2 and 3 , respectively. The measurements of radioactivity of the gel slices (Fig. 2) and autoradiography (Fig. 3) revealed that, in both partially purified and purified virus preparations, the host proteins were primarily localized in a few bands marked with dashed lines (Fig. 3).

The question arises whether the cellular proteins are constituents of the virion or simply contaminants. Several lines of evidence suggest that these host proteins are constituents of residual contaminating membranes. Briefly, (i) whereas the virus-specified proteins maintain relatively constant ratios with respect to one another during the last step in purification (with a few exceptions to be discussed), the host proteins are diminished in quantity with respect to the virus-specified proteins as a result of purification achieved in the flotation gradient (compare the left and right profiles of Fig. 2 and 3); that is, the host proteins appear to be separable from the virion proteins which themselves remain in constant ratio during the last step of purification. (ii) Labeled host proteins diminish in quantity (Table 1) to about the same extent as a result of flotation through the sucrose gradient, regardless of whether the label is incorporated into proteins of the same cells in which the virus was grown $\left({ }^{14} \mathrm{C}\right.$-amino acids added prior to infection, Fig. 3) or whether the label is from uninfected cells artificially mixed with the infected cells and therefore not incorporated into the virion during morphogenesis (Fig. 2). (iii) The most prominent host proteins present in the virus preparations have electrophoretic mobilities similar to those of major protein components of membrane contaminants, separated from the virus during the flotation gradient (electrophoretic profiles not shown), and of highly purified plasma membranes from infected or uninfected cells (Heine, Spear, and Roizman, manuscript in preparation).

As mentioned above, a few virus-specified proteins appear to be partially separable from the bulk of the virion components during the course of purification. To determine the nature of these proteins, the following series of experiments was done. First, partially purified (dextran gradient) virus labeled with ${ }^{14} \mathrm{C}$-amino acids was co-electrophoresed with purified (flotation gradient) virus labeled with ${ }^{3} \mathrm{H}$-amino acids. The radioactivity in each gel slice was measured by liquid scintillation spectrometry. As shown in Fig. 4A, the ratio of ${ }^{3} \mathrm{H}$-counts per minute to ${ }^{14} \mathrm{C}$-counts per minute was remarkably constant in all but two regions of the gel. To determine the nature of the proteins in these regions, we co-electrophoresed purified virions labeled with ${ }^{3} \mathrm{H}$-amino acids with purified virions labeled with ${ }^{14} \mathrm{C}$-glucosamine. The results shown in Fig. $4 \mathrm{C}$ indicate that the ${ }^{14} \mathrm{C}$-labeled glycoproteins migrated with the proteins selectively lost after flotation of the partially purified virus in sucrose gradients. Further evidence concerning the structures containing these glycoproteins is based on the previously reported observation that virusspecified glycoproteins present in preparations enriched in enveloped virus are electrophoretically indistinguishable from virus-specified glycoproteins present in purified cytoplasmic membranes $(13,23,29)$. This finding is again demonstrated by the profile in Fig. 4B which was obtained by the co-electrophoresis of purified virus labeled with ${ }^{3} \mathrm{H}$-amino acids and purified plasma membranes from cells labeled with ${ }^{14} \mathrm{C}$-amino acids after infection (prepared by J. Heine- see legend to Fig. 4). We conclude that the virus-specified glycoproteins are present both in contaminating membrane fragments and in the virion since (i) they are to a small extent separable from the bulk of the virion proteins and (ii) they are prominent components of the membrane con- 


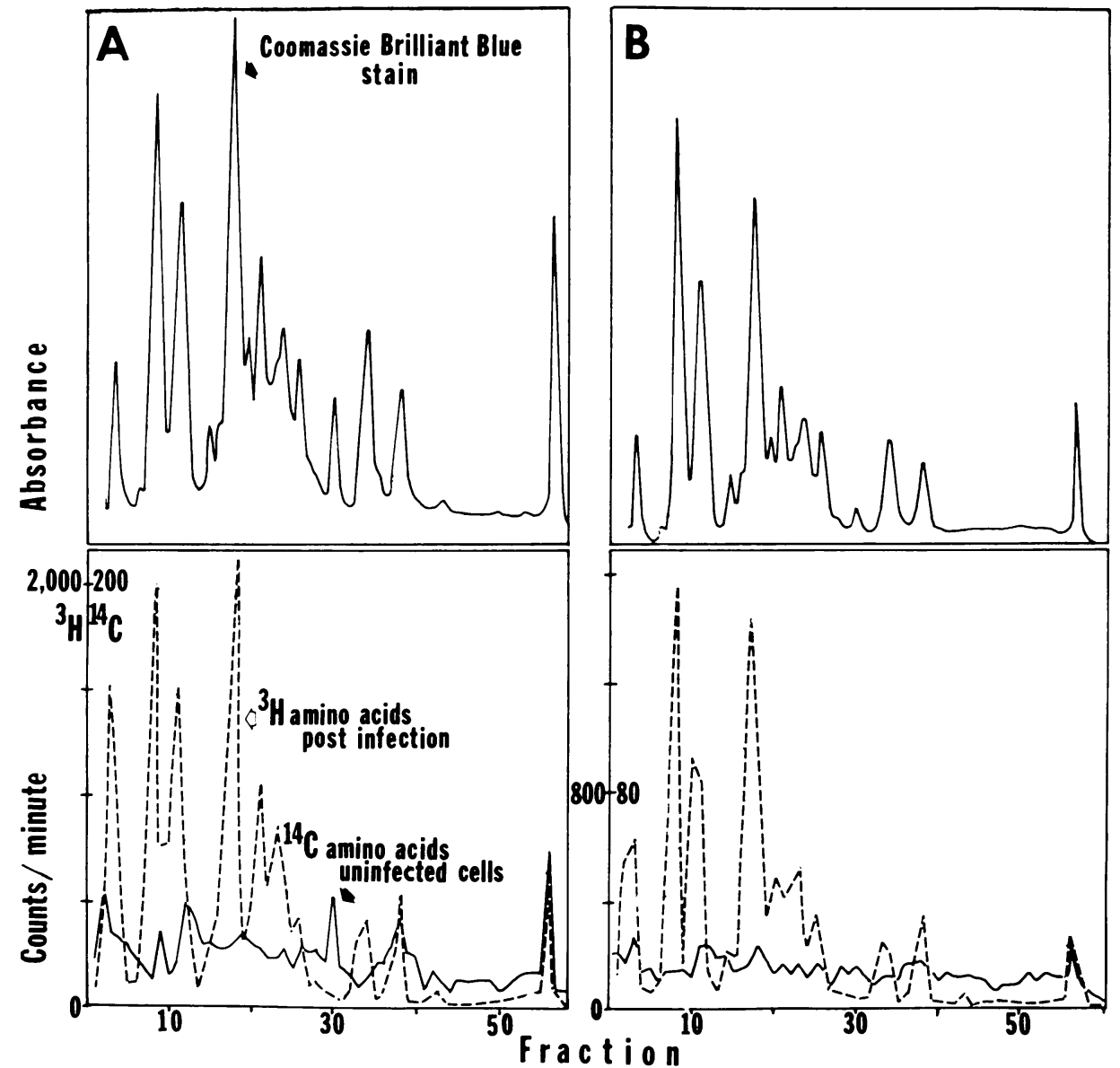

FIG. 2. Electropherograms of partially purified $(A)$ and purified $(B)$ virus prepared from an artificial mixture of ${ }^{3} \mathrm{H}$-amino acid-labeled infected cells and ${ }^{14} \mathrm{C}$-amino acid-labeled uninfected cells. The proteins were subjected to electrophoresis in 2-mm thick slabs of 9\% acrylamide. Absorbance profiles of the Coomassie Brilliant Blue-stained proteins are shown in the upper frames. Appropriate sections of the same slab were sliced into 1-mm sections and assayed by liquid scintillation spectroscopy to obtain the lower profiles. Electrophoresis is from left to right toward the anode in this and all following figures which show electropherograms. The peak at the extreme right of each profile is material that migrates with the bromophenol blue marker.

taminants separated from the virus during flotation in the sucrose gradients (not shown). The remainder of the virus-specified proteins are probably exclusively components of the virion since they remain in constant ratio during the final steps in purification.

Number and molecular weights of the virion proteins. The purpose of these experiments was to determine the number, electrophoretic mobilities, and hence $(25,34)$ the molecular weights of the virus-specific proteins present in the purified virions. In these experiments we prepared purified virus from cells labeled between 5 and $20 \mathrm{hr}$ postinfection either with ${ }^{14} \mathrm{C}$-amino acids or with ${ }^{14} \mathrm{C}$-glucosamine. The purified virus was then solubilized and subjected to electrophoresis on gels containing $6,8.5$, and $14 \%$ acrylamide.
Figure 5 is a photograph of Coomassie Brilliant Blue - stained bands of virion proteins separated in an $8.5 \%$ acrylamide gel. The proteins were labeled with ${ }^{14} \mathrm{C}$-amino acids. Absorbance profiles of the stained gel and of the autoradiogram made from the gel are shown in the left half of Fig. 6. Similar analyses of virion proteins labeled with ${ }^{14} \mathrm{C}$-glucosamine are shown in the right half of Fig. 6. Similar preparations subjected to electrophoresis in 6 and $14 \%$ acrylamide gels are shown in Fig. 7. The results of these analyses may be summarized as follows.

(i) The $8.5 \%$ acrylamide gels gave the best overall separation. In general, the ${ }^{14} \mathrm{C}$-amino acid autoradiograms and the absorbance profiles of the stained proteins agree remarkably well except in the right one-third of the gel, which 


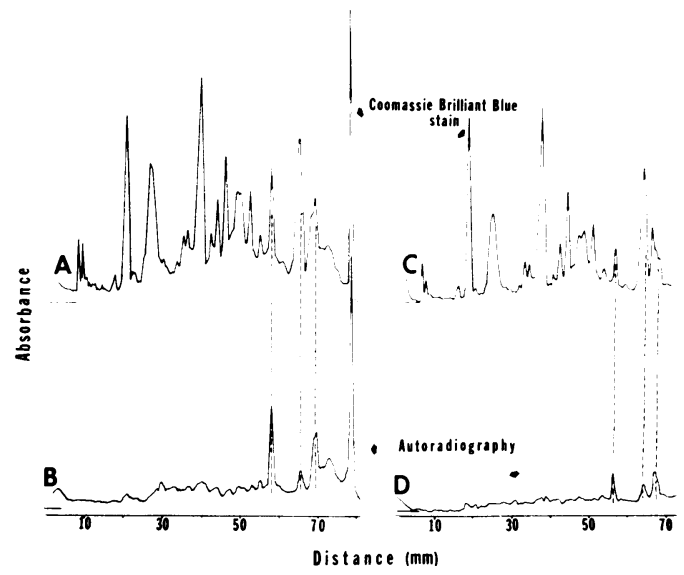

FIG. 3. Electropherograms of partially purified ( $A$ and $B$ ) and purified ( $C$ and $D$ ) virus prepared from cells which had been incubated with ${ }^{14} \mathrm{C}$-amino acids for $48 \mathrm{hr}$ prior to infection. The proteins were analyzed in cylinders of $8.5 \%$ acrylamide. Absorbance profiles of Coomassie Brillant Blue-stained gels and of autoradiograms prepared from the same gels are shown. The dashed lines mark the positions of the most prominent cellular proteins. All the proteins were better resolved in these electropherograms than in those of Fig. 2. The cellular proteins which migrate 57 to $58 \mathrm{~mm}$ from the origin in this figure correspond to those found in fraction 30 of Fig. 2. In this and following electropherograms, the position of the base line is indicated by a short line segment at the extreme left of the profile.

still shows traces of the host proteins identified in Fig. 2 and 3. The light radioisotopic labeling of the band numbered 22 is reproducible but unexplained. It may be that a significant proportion of the protein in this band is synthesized during the first $5 \mathrm{hr}$ of infection.

(ii) We have detected 24 virus-specific proteins in the virion. To distinguish these from other proteins specified by the virus, we shall designate the virion proteins as VP1 through VP24. Some bands were assigned two numbers because evidence exists that they contain at least two proteins. The two bands numbered VP1-3 can be resolved into three bands on $6 \%$ gels (Fig. 7). The bands labeled VP7-8 are known to contain two proteins because glucosamine label is distributed asymmetrically toward the leading edge (Fig. 4 and 6). VP7 may be either nonglycosylated or glycosylated to a lesser extent than VP8. Visual inspection of the stained bands in 6 and some $8.5 \%$ gels revealed that those labeled VP13-14 and VP17-18 consist of at least two proteins each. Electrophoresis of virion proteins in $14 \%$ acrylamide gels (Fig. 7) failed to reveal the presence of additional small-molecular-weight proteins in the virion. It should be reiterated that the bands given numerical designations are those which were highly reproducible in the appropriate gel concentrations. Thus the small blips between bands 3 and 4 were not reproducible, whereas bands $4,6,9,10,20$, and 24 were reproducible in appropriate gels both by Coomassie Blue staining and by autoradiography.

(iii) The glycoprotein peaks are reproducibly broad and exhibit some heterogeneity as evi-

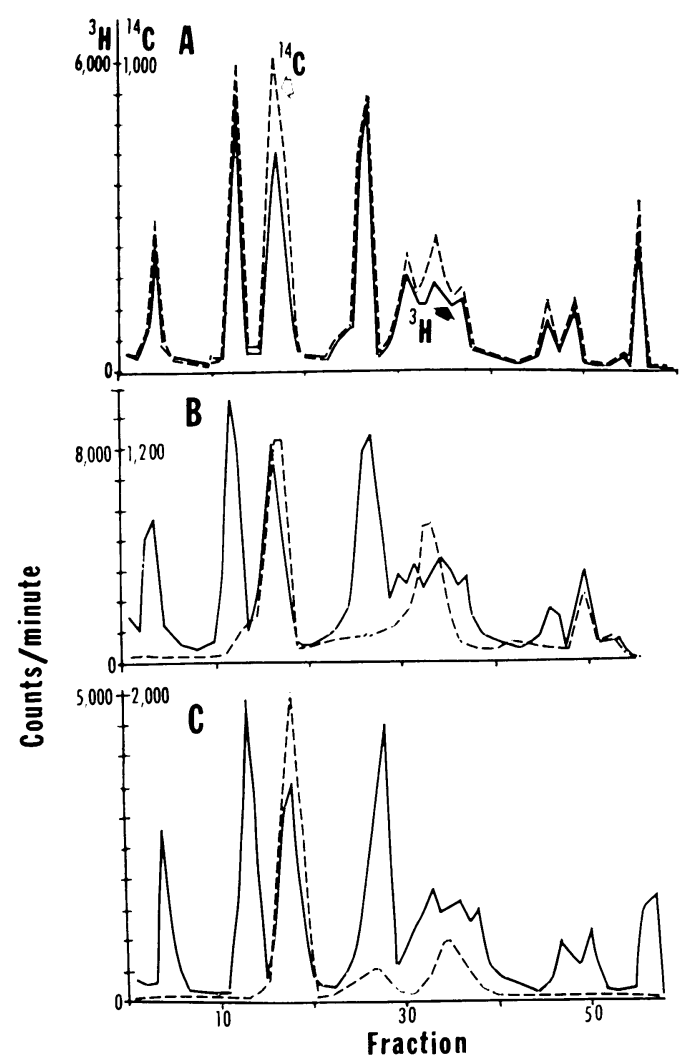

FIG. 4. Radioactivity profiles obtained after coelectrophoresis of purified virus labeled with ${ }^{3} \mathrm{H}$-amino acids (solid lines- $A, B$, and $C$ ) and partially purified virus labeled with ${ }^{14} C$-amino acids $(A)$, purified plasma membranes from cells incubated with ${ }^{14} \mathrm{C}$-amino acids postinfection $(B)$, or purified virus labeled with ${ }^{14} C$ glucosamine $(C)$. The $8.5 \%$ acrylamide gel cylinders were fractionated into 1-mm segments for analysis in a liquid scintillation counting system. The plasma membranes were prepared and characterized by J. Heine for studies to be published (Heine, Spear, and Roizman, manuscript in preparation). Panel $A$ indicates the virusspecified proteins that are removed with the residual contaminants in the last step of purification. These proteins have the same electrophoretic mobilities as the proteins indicated by the dashed lines in panels $B$ and $C$. 


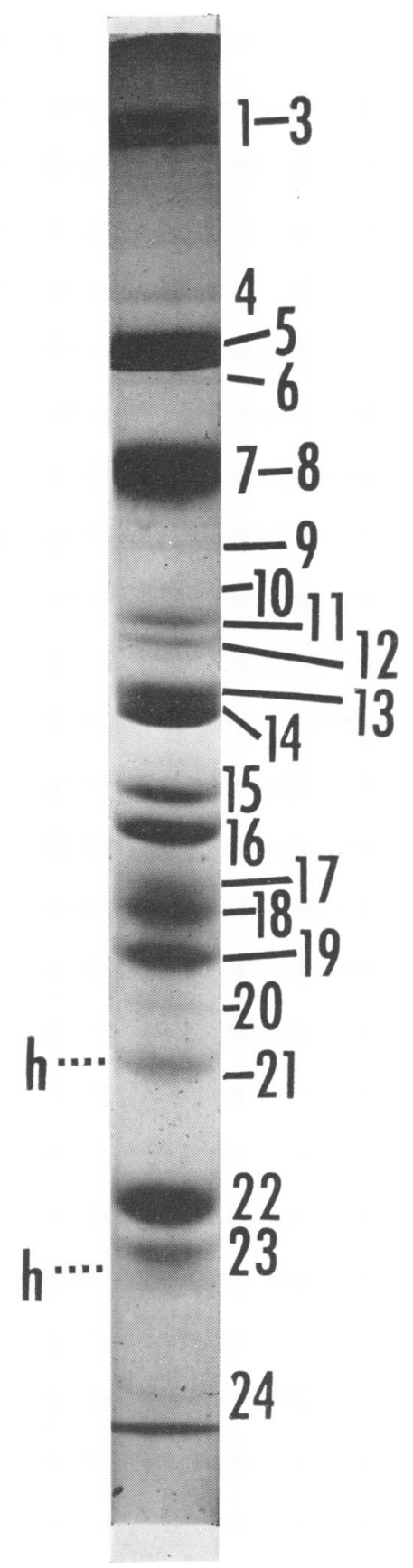

FIG. 5. Photograph of an $8.5 \%$ acrylamide gel stained with Coomassie Brilliant Blue after electrophoresis of the proteins of purified virus labeled with ${ }^{14} \mathrm{C}$-amino acids. The absorbance profile of this gel is shown in Fig. 6. The virus-specific protein bands have been assigned numbers from 1 to 24. The dark areas at the ends of the gel are due to uneven illumination. denced by visual inspection of stained gels and by the autoradiographic tracings, particularly of ${ }^{14} \mathrm{C}$-glucosamine-labeled proteins. We cannot state with any degree of certainty how many glycoproteins with distinct protein moieties are present in the virion nor precisely how many of the protein bands are glycosylated. Thus, it seems reasonably certain that VP8 and VP17 are glycosylated, but the bands near VP8 and VP17 may or may not be glycosylated. It is noteworthy that anomolies in the migration of glycoproteins in acrylamide gels have been reported (3).

(iv) It has been repeatedly demonstrated that the mobilities of proteins in SDS-acrylamide gels are inversely proportional to the logarithms of the molecular weights of the proteins $(25,34)$. An apparent exception to this is the observation by Bretscher (3) that the relative mobility of an erythrocyte glycoprotein varied depending on the concentration of acrylamide gel and yielded a range of molecular-weight estimates none of which agreed with the value obtained by another method. The anomolous behavior of the erythrocyte glycoprotein on acrylamide gel electrophoresis was not observed with herpesvirus glycoproteins (Table 4), suggesting that the molecular weight estimates are reliable. The relative mobilities of the protein standards and of the viral proteins in these gels are shown in Table 4 along with the molecular weights calculated from the mobilites of the viral proteins in each gel, the averaged molecular weights, and the sum of the calculated molecular weights of the virus-specific proteins. The data show a remarkable agreement between the molecular weights calculated from the migration of the proteins in different gels. The averaged molecular weights range from 25,000 to 275,000 daltons. The calculations summarized in Table 4 also indicate that the sum of the molecular weights of virus-specific structural proteins is approximately $2,580,000$ daltons.

Effect of NP-40 on virions. The effect of NP-40 on virions was determined both by electron microscopy and by comparison of electropherograms of treated and untreated virus. Partially purified virus (dextran band) was prepared from cells labeled with ${ }^{14} \mathrm{C}$-amino acids after infection. Half of the preparation was further purified by flotation in a discontinuous sucrose gradient and served as an untreated control. Virions were pelleted from the other half of the dextran band, resuspended in $0.01 \mathrm{M}$ Tris buffer, treated with $1 \%$ $\mathrm{NP}-40$ in $0.15 \mathrm{M} \mathrm{NaCl}$, and rebanded in a 20 to $50 \%$ sucrose gradient as described above. Electron micrographs of negatively stained NP-40treated and -untreated virus are shown in Fig. 8. 


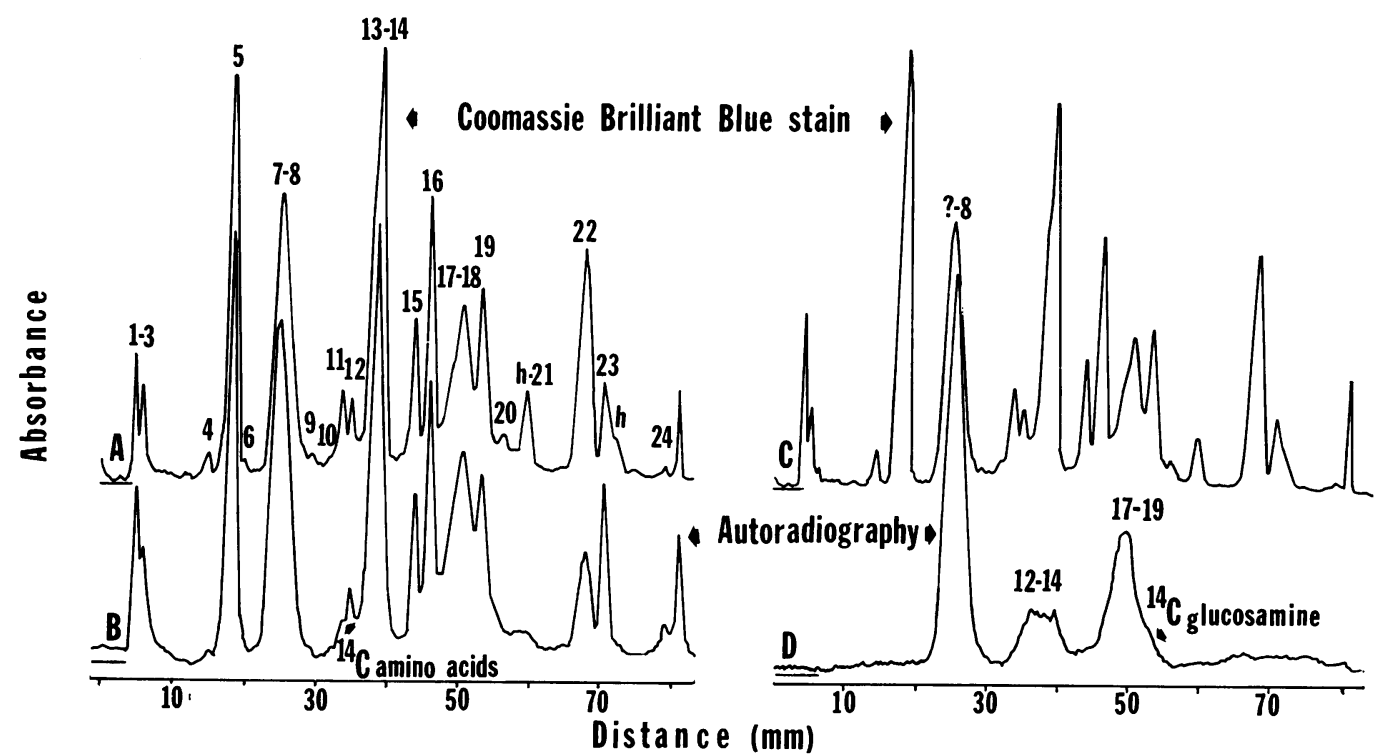

FIG. 6. Electropherograms of purified virion proteins labeled either with ${ }^{14} C$-amino acids $(A$ and $B)$ or ${ }^{14} C$ glucosamine $(C$ and $D)$. The absorbance profiles of Coomassie Brilliant Blue-stained gels $(8.5 \%$ acrylamide gel cylinders) and of autoradiograms developed from those same gels are shown. The virus-specific protein bands have been assigned numbers from 1 to 24 (VPI to VP24). The letter $h$ designates the positions of residual host proteins. In these and subsequent electropherograms, only bands reproducible from run to run were assigned numbers. The small blips between bands 3 and 4,21 and 22, and between 23 and 24 were not reproducible, whereas bands $4,6,9,10,20$, and 24 were reproducibly seen in gels of appropriate concentration.

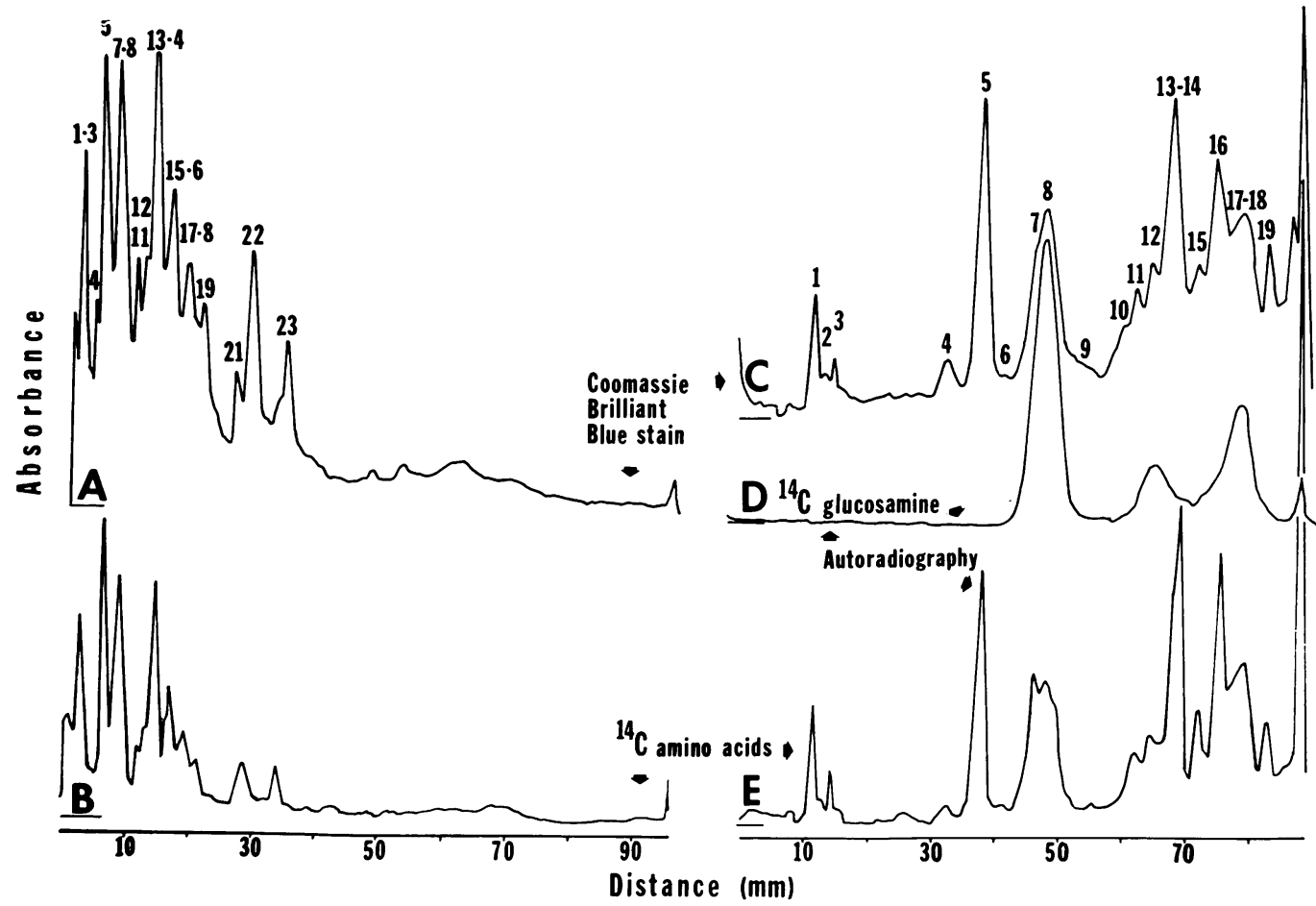

FIG. 7. Electropherograms of purified virion proteins in a $14 \%$ gel slab (A and B) and $6 \%$ gel cylinders $(C, D$, and $E$ ). Shown here are the absorbance profiles of Coomassie Brilliant Blue-stained gels $(A$ and $C)$ and of autoradiograms which detect proteins labeled after infection with ${ }^{14} C$-amino acids $(B$ and $E)$ or ${ }^{14} C$-glucosamine $(D)$. 
TABLE 4. Relative migration rates and molecular weights of viral proteins

\begin{tabular}{|c|c|c|c|c|c|c|c|c|c|c|}
\hline \multirow{2}{*}{ Protein } & \multicolumn{4}{|c|}{ Migration relative to bromophenol blue $e^{a}$} & \multirow{2}{*}{$\begin{array}{c}\text { Known } \\
\text { molecular } \\
\text { weight } \\
\times 10^{-3}\end{array}$} & \multicolumn{4}{|c|}{ Calculated molecular weight ${ }^{c}$} & \multirow{2}{*}{$\begin{array}{l}\text { Avg. } \\
\text { calculated } \\
\text { molecular } \\
\text { weight } \\
\times 10^{-3 d}\end{array}$} \\
\hline & $6 \%$ Gel & $7 \% \mathrm{Gel}$ & $8.5 \%$ Gel & $9 \%$ Gel & & $6 \%$ Gel & $i \%$ Gel & $8.5 \%$ Gel & $9 \%$ Gel & \\
\hline \multicolumn{11}{|l|}{ Known standards } \\
\hline Myosin & & 0.19 & & 0.10 & 220 & & & & & \\
\hline$\beta$-Galactosidase & & 0.42 & & 0.24 & 130 & & & & & \\
\hline Lactoperoxidase & 0.70 & 0.56 & 0.43 & 0.35 & 92.6 & & & & & \\
\hline $\begin{array}{l}\text { Bovine serum } \\
\text { albumin }\end{array}$ & 0.80 & 0.67 & 0.53 & 0.44 & 68 & & & & & \\
\hline Ovalbumin & & 0.92 & 0.75 & 0.68 & 43 & & & & & \\
\hline $\begin{array}{c}\alpha \text {-Chymotryp- } \\
\text { sinogen A }\end{array}$ & & & 0.97 & 0.91 & 25.7 & & & & & \\
\hline \multicolumn{11}{|l|}{ Viral proteins } \\
\hline 1 & & 0.10 & & 0.05 & & & 270 & & 280 & 275 \\
\hline 2 & & 0.11 & & 0.06 & & & 255 & & 265 & 260 \\
\hline 3 & & 0.11 & & 0.06 & & & 255 & & 265 & 260 \\
\hline 4 & & 0.27 & & 0.14 & & & 182 & & 185 & 184 \\
\hline 5 & & 0.34 & & 0.19 & & & 155 & & 155 & 155 \\
\hline 6 & & 0.36 & & 0.21 & & & 150 & & 142 & 146 \\
\hline 7 & & 0.43 & & 0.25 & & & 127 & & 125 & 126 \\
\hline 8 & & 0.43 & & 0.25 & & & 127 & & 125 & 126 \\
\hline 9 & & 0.48 & & 0.29 & & & 113 & & 110 & 112 \\
\hline 10 & 0.69 & 0.54 & 0.40 & 0.33 & & 95 & 99 & 100 & 97 & 98 \\
\hline 11 & 0.71 & 0.57 & 0.42 & 0.35 & & 91 & 93 & 95 & 92 & 93 \\
\hline 12 & 0.74 & 0.60 & 0.44 & 0.38 & & 84 & 86 & 90 & 86 & 87 \\
\hline 13 & 0.78 & 0.64 & 0.49 & 0.42 & & 77 & 79 & 80 & 77 & 78 \\
\hline 14 & 0.78 & 0.64 & 0.49 & 0.42 & & 77 & 79 & 80 & 77 & 78 \\
\hline 15 & 0.82 & 0.68 & 0.55 & 0.46 & & 70 & 72 & 70 & 70 & 71 \\
\hline 16 & 0.86 & 0.72 & 0.57 & 0.49 & & 63 & 66 & 66 & 65 & 65 \\
\hline 17 & 0.89 & 0.76 & 0.63 & 0.52 & & 59 & 60 & 57 & 61 & 59 \\
\hline 18 & 0.92 & 0.78 & 0.63 & 0.54 & & 55 & 58 & 57 & 58 & 57 \\
\hline 19 & 0.94 & 0.83 & 0.66 & 0.58 & & 52 & 52 & 53 & 53 & 53 \\
\hline 20 & & 0.85 & 0.69 & 0.61 & & & 49 & 50 & 50 & 50 \\
\hline 21 & & 0.91 & 0.75 & 0.66 & & & 43 & 43 & 45 & 44 \\
\hline 22 & & 0.97 & 0.84 & 0.74 & & & 38 & 35 & 37 & 37 \\
\hline 23 & & & 0.88 & 0.80 & & & & 32 & 33 & 33 \\
\hline 24 & & & 0.98 & & & & & 25 & & 25 \\
\hline
\end{tabular}

a Taken as 1.00 .

${ }^{b}$ Molecular weights are as given by Weber and Osborn (34) and by Theorell and Pedersen (32).

$c$ Calculated to nearest 1,000 daltons only through the range spanned by the known protein standards used.

${ }^{d}$ Sum of the molecular weights of viral proteins shown in this column is $2,580,000$ daltons.

Although NP-40 destroyed the normal morphology of the virion envelope, some amorphous material remained adherent to the nucleocapsid even after banding of the treated virus in a sucrose gradient. Electrophoretic analyses of the NP-40treated and -untreated preparations (Fig. 9) revealed the following. (i) As a result of NP-40 treatment, many proteins were diminished in quantity relative to VP-5, which is probably a major capsid component (33). (ii) The glycoproteins were extracted to a greater extent than the others; in fact, glycoprotein(s) migrating in the position of VP7-8 were almost quantitatively extracted. We conclude that the glycoproteins can be preferentially extracted from the virion without the complete removal of all envelope material. The question remains as to which and how many of the virion proteins are associated with the envelope rather than the nucleocapsid.

\section{DISCUSSION}

In this paper we are reporting a procedure for the purification of herpesvirions; the number, relative mobilities, and estimated molecular weights of the structural proteins; and the effect of the nonionic detergent NP-40 on virions. Several comments should be made as follows.

(i) Our data suggest that the main contaminants 


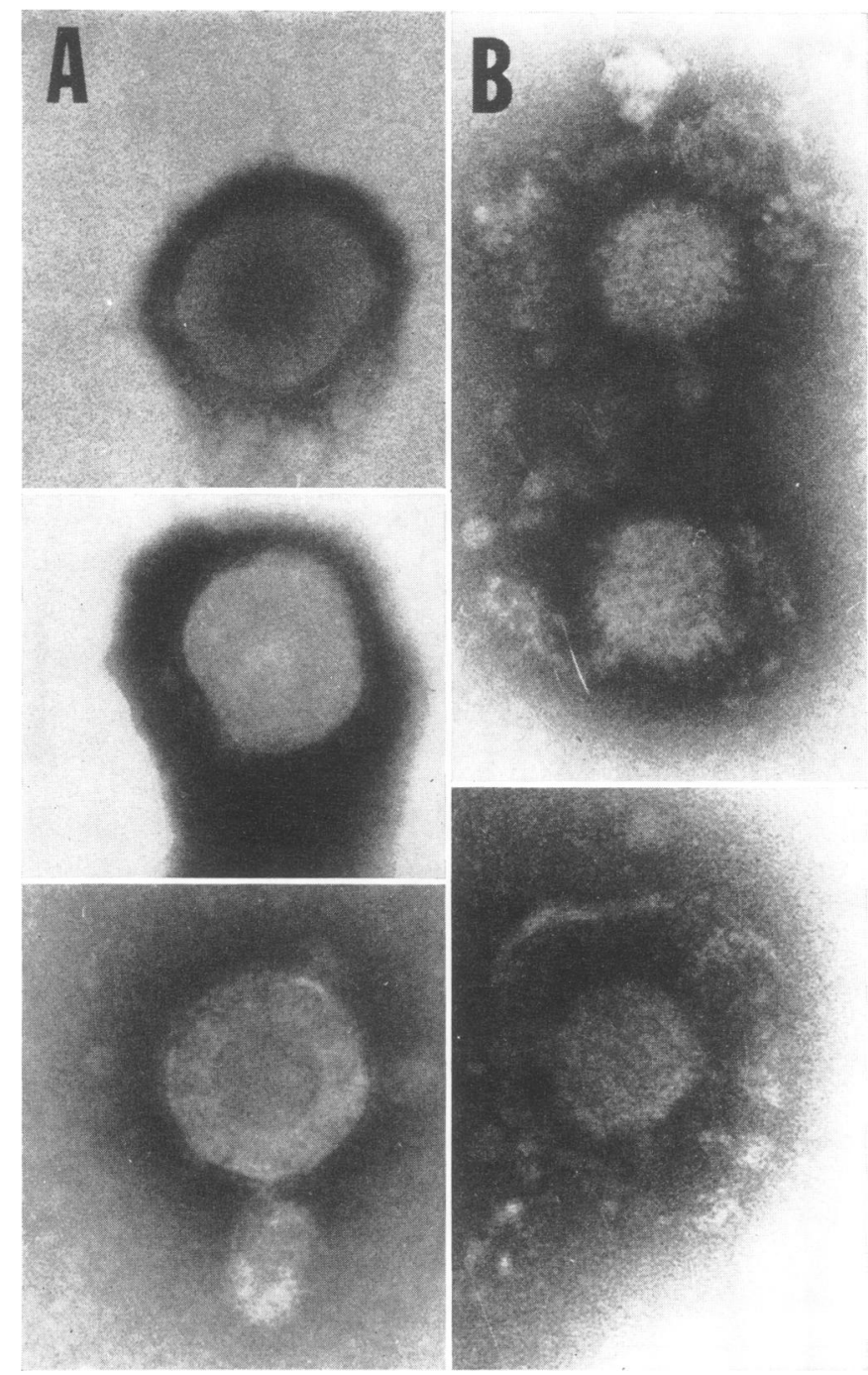

FIG. 8. Electron micrographs of negatively stained virus particles in whole mount preparations. Untreated purified virions are shown in column $A$. The stain does not penetrate the intact envelope; protrusions on the surface of the envelope are barely visible. Virus particles treated with Nonidet $P-40$ and banded in a sucrose density gradient are shown in column B. The characteristic morphology of the envelope is destroyed; however, an amorphous material adheres to the nucleocapsids.

of the herpesvirion preparations are cellular membranes. Although we have achieved substantial purification, some host proteins still remain in these preparations. Data to be published elsewhere (Heine, Spear, and Roizman, manuscript in preparation) indicate that these proteins are also present in highly purified plasma membranes from both infected and uninfected cells. The residual host proteins are therefore either in the envelope of the virus or in fragments of cell membranes contaminating the virus preparations. We cannot at present exclude either possibility, but, even if these proteins are in the envelope of the virus, they are at best relatively minor structural constituents of the virion. The fact that these proteins do not remain in constant ratio to the virusspecific structural proteins during the last stages of purification leads us to suspect that they represent residual contaminating membranes and that the membranes which ultimately give rise to the envelope of the virion are either made de novo after infection or are reorganized to the extent that all host proteins are ejected.

(ii) In the virion, we have detected 24 proteins which are made after infection and are presumably virus-specific structural proteins. This is the 


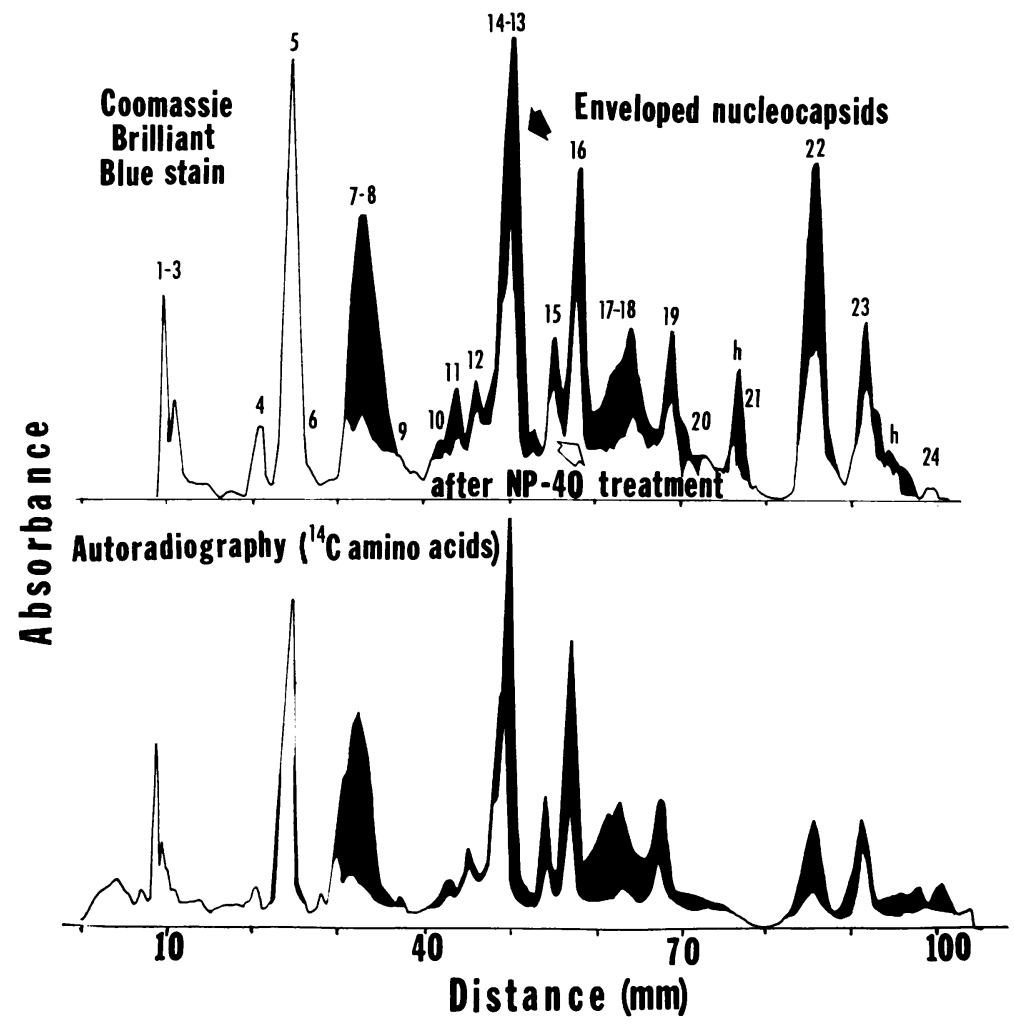

FIG. 9. Electropherograms of the proteins of purified virions and of Nonidet P-40 (NP-40)-treated virus, both labeled with ${ }^{14} \mathrm{C}$-amino acids. Absorbance profiles of Coomassie Brilliant Blue-stained gels (top) and of autoradiograms (bottom) developed from the same gels are shown. The profiles obtained from control and NP-40-treated preparations were superimposed and normalized so that the areas under peak VP5 were approximately the same. The shaded areas indicate losses of structural proteins relative to VP-5 as a result of treatment with NP-40 and centrifugation in a sucrose density gradient.

highest number reported to date; yet, it is a minimal estimate, and, conceivably, minor proteins species may be masked by the major bands. The number of virus-specific structural proteins detected in this study differs markedly from those reported by Kaplan and Ben-Porat (12) and by Olshevsky and Becker (17). The differences are in large part due to the much greater purity of the virions, which resulted in a reduction of the background in acrylamide gels and made minor species of structural proteins readily apparent, and the high-resolution electrophoresis technique which probably doubled the number of resolvable protein bands.

(iii) The molecular weights of viral proteins estimated in several concentrations of acrylamide gels range from 25,000 to 275,000 daltons. Two points should be made. First, it is conceivable that some of the high-molecular-weight proteins are aggregates of two or more proteins. However, (i) the relative amounts of the high $(>100,000)$ molecular-weight proteins were highly reproducible from experiment to experiment. (ii) The high- molecular-weight proteins were unaffected by reduction and alkylation of virion proteins in the presence of $6 \mathrm{M}$ guanidine (unpublished data). (iii) Viral ribonucleic acid (RNA) species with sedimentation coefficients of approximately $35 \mathrm{~S}$ are present in cytoplasmic polyribosomes (22) Such RNA molecules are approximately $2.5 \times$ $10^{6}$ daltons in molecular weight. This amount of RNA is sufficient to specify polypeptide chains 280,000 daltons in molecular weight. (iv) A very substantial and readily measurable increase in the sedimentation coefficient of polyribosomes after infection has also been reported $(30,31)$. The second point concerns the lower limit of the molecular weights of virus-specific structural proteins. Both Coomassie Brilliant Blue stain and the autoradiographic analyses of the $14 \%$ gels failed to reveal virus-specific proteins less than 25,000 daltons in molecular weight. Our data indicate that proteins less than 25,000 daltons, if present, are not major structural components of the herpes simplex virions.

(iv) The sum of the molecular weights of the 24 
virus-specific structural proteins detected to date amounts to roughly $2,580,000$ daltons, i.e., nearly double the number reported by Abodeely et al. (2), although they detected 20 structural proteins for equine abortive virus as compared to the 24 reported here. On the basis of the molecular weight of $99 \times 10^{6} \pm 5 \times 10^{5}$ daltons for herpes simplex virus deoxyribonucleic acid (DNA) (14), the absence of significant amounts of repetitive sequences (10), and the assumption that viral mRNA is transcribed asymmetrically and is not complementary, it can be calculated that the DNA has sufficient genetic information to specify the sequence of 55,000 amino acids. The data presented in this study indicate that approximately 25,800 amino acids, or $47 \%$ of the genetic information, is concerned with the structural proteins of the virus. Our enthusiasm for this statistic must be tempered by the remote possibility that some of the large proteins may be aggregates of two or more polypeptides and by the more likely possibility that some viral proteins still remain undetected.

(v) Although the molecular weights of the virion proteins have been calculated with reasonable internal consistency, the data collected in this paper are not sufficient to calculate the molar ratios of the various structural proteins of the virus. The reasons for this are twofold. First, it is not entirely clear that the absorbance of the Coomassie Brilliant Blue stain bears a constant relationship to the actual protein concentration in each band. Parenthetically, in our hands, some bands (particularly glycoproteins) stained slightly different colors than the rest. We suspect that the absorbance measurements at $550 \mathrm{~nm}$ do not correspond precisely to the protein concentration. The second reason relates to the fact that the labeling with ${ }^{14} \mathrm{C}$-amino acids was begun at $5 \mathrm{hr}$ postinfection, i.e., after the synthesis of structural proteins had already begun.

(vi) The experiments with NP-40 were prompted by various reports concerning the effects of nonionic detergents on the envelope of the virus. Abodeely et al. (1) reported that $2.5 \%$ NP-40 combined with sonic treatment stripped the envelope of equine abortion virus as determined by electron microscopic examination. Kaplan and Ben-Porat (12) also reported the appropriate conditions for the complete removal of pseudorabies envelopes with Triton X-100-again by electron microscopic criteria. Both groups reported the removal of glycoproteins from virus concomitant with stripping of the envelopes (2, 12). On the other hand, Olshevsky and Becker (17) reported that NP-40 selectively extracts two of the three glycoproteins detected in their gel system. Under the conditions of our studies,
NP-40 leaves residual envelope material still adhering to the nucleocapsids. Moreover, extraction of glycoproteins is neither entirely complete nor entirely selective. Since the glycoproteins are very likely structural components of the envelope, it seems clear that in our hands NP-40 disrupts the envelope but does not entirely remove it. We are, on the other hand, concerned with the fact that nonglycosylated proteins are also extracted by NP-40. It remains to be seen whether these are components of the envelope or of the capsid.

\section{ACKNOWLEDGMENTS}

We acknowledge Patricia Wiedner for assistance with the electron microscopy and George Gibson for the design and construction of the slab gel electrophoresis apparatus used in these studies.

These studies were supported by U.S. Public Health Service grant CA 08494 from the National Cancer Institute, American Cancer Society grant E 314F, and National Science Foundation grant GB-27356. P. G. Spear is a postdoctoral trainee supported by Public Health Service grant TO1HD 00297 from the National Institute of Child Health and Human Development.

\section{ADDENDUM IN PROOF}

Since this paper was submitted for publication other studies from our labcratory have demonstrated the following. (i) Highly purified plasma membranes from infected cells contain virusspecific proteins with electrophoretic mobilities identical to virion proteins $7,8,11,12,13,14,17,18,22,23,24$. The glycosylation patterns of these proteins follow closely those of the virion prcteins (Heine, Spear, and Rcizman, submitted for publication). In view of the fact that they are present in membranes we conclude that they may be among the protein constituents of the envelcpe. (ii) Analysis of solubilized whole infected cells and of NP-40 extracts of the same cells revealed substantial amounts of glycosylated proteins with electrophcretic mobilities of VP11 and VP19. In addition, glycosylated proteins with electrophoretic mobility of VP15 and VP16 were also detected (Savage and Roizman, manuscript in preparation). We conclude that infected cells contain at least 12 glycosylated proteins, some in different propcrtion than are found in the purified virion or in the purified plasma membrane. The glycosylated proteins are $7,8,11,12,13,14,15,16,17,18$, 19 , and 21 .

\section{LITERATURE CITED}

1. Abodeely, R. A., L. A. Lawson, and C. C. Randall. 1970. Morphology and entry of enveloped and de-enveloped equine abortion (herpes) virus. J. Virol. 5:513-523.

2. Abodeely, R. A., E. Palmer, L. A. Lawson, and C. C. Randall. 1971. The proteins of enveloped and de-enveloped equine abortion (herpes) virus and the separated envelope. Virology 44:146-152.

3. Bretscher, M. S. 1971. Major human erythrocyte glycoprotein spans the cell membrane. Nature (London) 231:229-232.

4. Darlington, R. W., and L. H. Moss. III. 1968. Herpesvirus envelopment. Virology 2:48-55.

5. Davis, B. J. 1964. Disc electrophoresis. II. Method and application to serum proteins. Ann. N.Y. Acad. Sci. 121: 404.

6. Dimmock, N. J., and D. H. Watson. 1969. Proteins specified by influenza virus in infected cells: analysis by polyacrylamide gel electrophoresis of antigens not present in the virus particles. J. Gen. Virol. 5:499-509.

7. Ejercito, P. M., E. D. Kieff, and B. Roizman. 1968. Characterization of herpes simplex virus strains differing in thei effect on social behavior of infected cells. J. Gen. Virol. 3:357--364. 
8. Fairbanks, G., Jr., C. Levinthal, and R. H. Reeder. 1965. Analysis of $\mathrm{C}^{1}{ }^{1}$-labeled proteins by disc electrophoresis. Biochem. Biophys. Res. Commun. 20:393-399.

9. Fairbanks, G., T. L. Steck, and D. F. H. Wallach. 1971 Electrophoretic analysis of the major polypeptides of the human erythrocyte membrane. Biochemistry 10:2606-2617.

10. Frenkel, N. and B. Roizman. 1971. Herpes simplex virus genome size and redundancy studied by renaturation kinetics. J. Virol. 8:591-593

11. Hoggan, M. D., and B. Roizman. 1959. The effect of the tem perature of incubation of the formation and release of herpes simplex virus in infected FL cells. Virology 8:508524.

12. Kaplan, A. S., and T. Ben-Porat. 1970. Synthesis of proteins in cells infected with herpesvirus. VI. Characterization of the proteins of the viral membrane. Proc. Nat. Acad. Sci U.S.A. 66:799-806.

13. Keller, J. M., P. G. Spear, and B. Roizman. 1970. The proteins specified by herpes simplex virus. III. Viruses differing in their effects on the social behavior of infected cells specify different membrane glycoproteins. Proc. Nat. Acad. Sci. U.S.A. 65:865-871.

14. Kieff, E. D., S. L. Bachenheimer, and B. Roizman. 1971. Size, composition, and structure of the deoxyribonucleic acid of herpes simplex virus subtypes 1 and 2. J. Virol. 8: 125-132.

15. Laemmli, U. K. 1970. Cleavage of structural proteins during the assembly of the head of bacteriophage T4. Nature (London) 227:680-684.

16. Lim, R., J. J. Huang, and G. Y. Davis. 1969. Autoradiography with acrylamide gel slab electrophoresis. Anal. Biochem. 29:48-57.

17. Olshevsky, U., and Y. Becker. 1970. Herpes simplex virus structural proteins. Virology 40:948-960.

18. Robinson, D. J., and D. H. Watson. 1971. Structural proteins of herpes simplex virus. J. Gen. Virol. 10:163-171.

19. Roizman, B. 1969. Herpesviruses-a biochemical definition of the group, p. 1-79. In B. Benacerraf et al. (ed.), Current topics in microbiology and immunolcgy, vol. 49. SpringerVerlag, Heidelberg.

20. Roizman, B., and P. R. Roane, Jr. 1963. Demonstration of a surface difference between virions of two strains of herpes simplex virus. Virology 19:198-204.

21. Roizman, B., and P. G. Spear. 1971. Herpesvirus antigens on cell membranes detected by centrifugation of membraneantibody complexes. Science 171:298-300.

22. Roizman, B., S. L. Bachenheimer, E. K. Wagner, and T. Savage. 1970. Synthesis and transport of RNA in herpesvirus infected mammalian cells. Cold Spring Harbor Symp. Quant. Biol. 35:753-771.

23. Schwartz, J., and B. Roizman. 1969. Concerning the egress of herpes simplex virus from infected cells: electron microscope observations. Virology 38:42-49.

24. Schwartz, J., and B. Roizman. 1969. Similarities and dif ferences in the development of laboratory strains and freshly isolated strains of herpes simplex virus in HEp-2 cells: electron microscopy. J. Virol. 4:879-889.

25. Shapiro, A. L., E. Viñuela, and J. V. Maizel, Jr. 1967. Molecular weight estimation of polypeptide chains by electrophoresis in SDS-polyacrylamide gels. Biochem. Biophys. Res. Commun. 23:815-820.

26. Spear, P. G., and B. Roizman. 1968. The proteins specified by herpes simplex virus. I. Time of synthesis, transfer into nuclei, and proteins made in productively infected cells. Virology 36:545-555.

27. Spear, P. G., J. M. Keller, and B. Roizman. 1970. Proteins specified by herpes simplex virus. II. Viral glycoproteins associated with cellular membranes. J. Virol. 5:123-131.

28. Steck, T. L., J. H. Straus, and D. F. H. Wallach. 1970. A model for the behavior of vesicles in density gradients: implications for fractionation. Biochem. Biophys. Acta 203:385-393.

29. Summers, D. F., J. V. Maizel, Jr., and J. E. Darnell, Jr. 1965 Evidence for virus-specific proteins in poliovirus-infected HeLa cells. Proc. Nat. Acad. Sci. U.S.A. 54:505-513.

30. Sydiskis, R. J., and B. Roizman. 1966. Polysomes and protein synthesis in cells infected with a DNA virus. Science 153: 76-78.

31. Sydiskis, R. J., and B. Roizman. 1967. The disaggregation of host polyribosomes in productive and abortive infections with herpes simplex virus. Virology 32:678-686.

32. Theorell, H., and K. O. Pedersen (cited by J. Wyman Jr.) 1948. Heme proteins. Advan. Protein Chem. 4:407-531.

33. Watson, D. H. 1968. The structure of animal viruses in relation to their biological functions. Symp. Soc. Gen. Microbiol. 18:207-229.

34. Weber, K., and M. Osborn. 1969. The reliability of molecular weight determinations by dodecyl sulfate-polyacrylamide gel electrophoresis. J. Biol. Chem. 244:4406-4412. 